\title{
Effect of Boosting Solar Radiation Intensity on Thermal and Hydraulic Performance and Characteristics of Forced Circulation Food Dryer Provided with Roughened Solar Air Heater
}

\author{
Manoj Kumar Singh, Gupta Nath Sah
}

\begin{abstract}
This paper focus on effects of boosting solar intensity on the thermal performance of solar food dryer coupled with roughened solar heater. Boosting of solar intensity increases the temperature of air entering into the food dryer without changing the specific humidity. The methods which have been used to increase the intensity of incidence radiation on the collector of food dryer are plane mirrors with tracking, parabolic reflectors and compound parabolic concentrator. It has been observed experimentally that boosting intensity improves performance characteristics of solar air heater and food dryer. It increases collector efficiency, dryer efficiency, loss of moisture content and diminishes the moisture content in the product at any time.

Keywords: Moisture, booster mirror, food dryer, pyranometer, artificial roughness
\end{abstract}

\section{INTRODUCTION}

Because of gradual depletion of non- renewable energy sources, scientists and engineered have been trying for decades to search for new alternative energy sources. Solar energy being clean, environmental friendly and profusely available energy source, a large research and development effort is underway to develop economical system to harness solar energy, efficiently as major source fuel energy for heating and cooling of buildings, air heaters, water heaters, and photovoltaic panel and food/crop dryers. Higher temperature of air heater and dryer can be achieved by creating turbulence in the flow and boosting solar intensity. Mass transfer of moisture from crop can be enhanced by using different method of boosting solar intensity.

Rizwan Arshad Salman Tareq [1] discussed improvement of solar panel efficiency by introducing plane mirrors as solar concentrators. L. Mohamad , M Alyer and I. Gahaba [2] investigated the performance of transacted pyramid solar cooker and find absorber plate temperature increases from $119^{\circ} \mathrm{c}-138^{\circ} \mathrm{c}$ using booster reflector and efficiency from

Revised Manuscript Received on April 27, 2020.

* Correspondence Author

Manoj Kumar Singh*, Department of Mechanical Engineering, B. I. T Sindri, Dhanbad, India Email: mksbit793@gmail.com

Gupt Nath shah, Ex retired professor, department of Mechanical Engineering, B.I.T Sindri, Dhanbad, India Email: gnash.bit@gmail.com

(C) The Authors. Published by Blue Eyes Intelligence Engineering and Sciences Publication (BEIESP). This is an open access article under the CC BY-NC-ND license (http://creativecommons.org/licenses/by-nc-nd/4.0/)
25.3\% to 53\%. Priya Pannorsevam, Lavanya Sabromanian and Vimal Perumal[3] conducted experiment using booster solar energy fuel Single phase boost convertor for bringing constant output voltage of solar panel.

Muhammad Bilal, Muhammad Nasem Arbab Nd Muhammad Zain [4] carried out detail study of increasing output power and efficiency of concentrator s photovoltaic (CPU) panel by using concentrating mirror.

Yang yan and Yeu D [5] carried out investigation of increasing efficiency and Awed output of solar Panel using plane mirror at different angles and solar radiation concentrators.

The aim of the present paper is to carry out experimental investigation on the thermal performance of solar food/ crops dryer for different food products coupled with roughened solar air heater at different roughness parameter using tracking plane mirror for boosting solar intensity. Roughness on the absorber plate was provided by copper wires of different diameters at different fitches. Mass flow rate of air was varied with induction fan by cabbage, cauliflower and red chilies.

\section{A. Performance of solar dryer}

Drying includes both warmth and mass exchange activities at the same time and consequently, execution can be anticipated by estimating dampness content whenever (for example at a specific sun based power) temperature, dampness and sun-powered force.

Impacts of temperature on the loss of dampness content (i.e humidification of air going into nourishment dryer.On the off chance that temperature of the air leaving structure air warmer builds structure tA to tA' at that point misfortune dampness from nourishment dryer increments from (WB - WA) to (WB - to WA') per kg of dry air.

$$
\begin{gathered}
\dot{\mathrm{m}}_{\mathrm{a}=} \frac{\dot{\mathrm{m}}_{m}}{W_{2}-W_{1}}=\frac{m_{i}-m_{f}}{W_{2}-W_{1}} \\
f_{\mathrm{d}}=\frac{\dot{\mathrm{m}}_{m}}{\dot{\mathrm{m}}_{f}} \times 100=\frac{m_{i}-m_{f}}{m_{i}} \times 100
\end{gathered}
$$

$$
\eta_{\mathrm{c}}=\frac{\text { Rate of the heat carried away by air in the air in }}{\text { Rate of solar energy incident }}
$$

$$
\eta_{\mathrm{d}}=\frac{\operatorname{maxCpa}(\mathrm{t} 1-\mathrm{t} 2)}{I \times A c}
$$

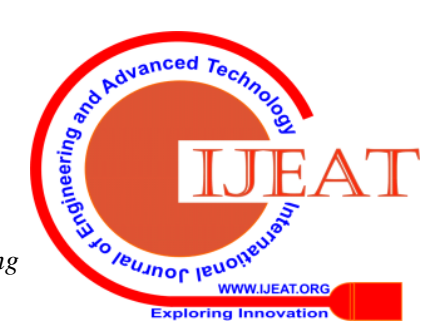


Effect of Boosting Solar Radiation Intensity on Thermal and Hydraulic Performance and Characteristics of Forced Circulation Food Dryer Provided with Roughened Solar Air Heater

$$
\begin{gathered}
\eta_{\mathrm{d}=} \frac{\dot{\mathrm{m}}_{a} \times h_{f g}}{\dot{\mathrm{m}}_{a} \times C p a \times\left(t_{1}-t_{2}\right)} \\
\mathrm{HUF}=\frac{t_{1}-t_{2}}{t_{1}-t_{i}} \quad \mathrm{t}_{2}>\mathrm{t}_{\mathrm{i}} \text { and } \mathrm{t}_{2}<\mathrm{t}_{1} \\
C O P=\frac{t_{2}-t_{i}}{t_{1}-t_{i}} \\
\text { HUF }+ \text { COP }=1
\end{gathered}
$$

Based on above principle we can increase the thermal performance of food dryer by increasing out let temperature of air from the air heater by providing roughness over collector plate. The rate of loss of moisture can be further increased by forced circulation i.e. increasing mass flow.

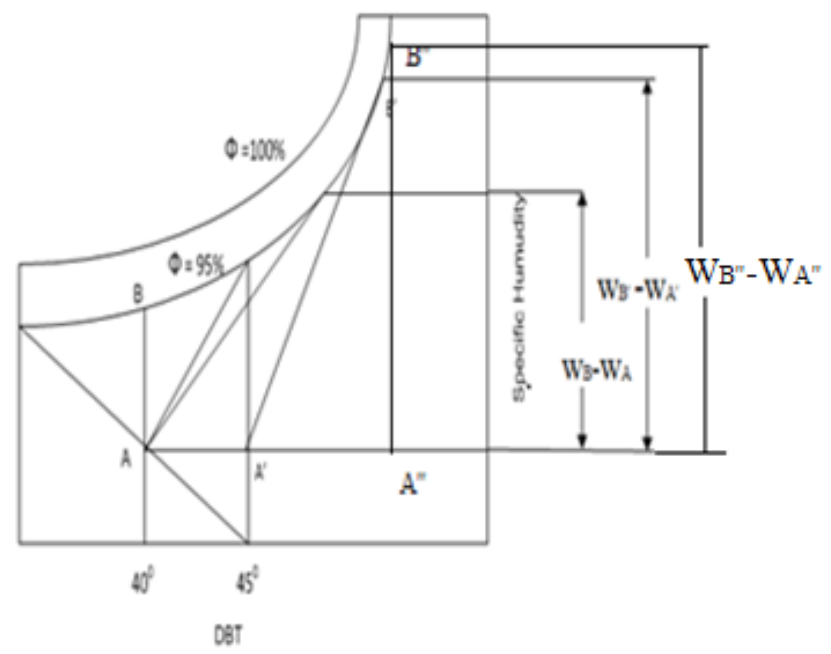

Fig 1 Specific Humidity graph

\section{B. Objective of present investigation}

In perspective on the next to no data accessible in different parts of diagnostic and trial execution of sun based nourishment dryer with counterfeit harshness over authority plate, this examination concerning heat move and mass exchange attributes has been taken up.

A broad test examination has been completed for dampness misfortune rate for items like cauliflower, cabbage, cold and wheat with variable harshness $(\varepsilon / D)$ and $\mathrm{P} / \varepsilon$ ) at variable mass stream pace of air into sun based air warmer and sun-powered nourishment dryer. Both warmth and mass exchange increments with increment in Reynolds number and if harshness close to the gatherer plate is more than the laminar sublayer thickness, convective warmth moves from the plate to air increments.

The trial arrangement comprises of ringer mounted sun based air warmer channel made of pack handle, combined with a cupboard and a smokestack, copper wire of various distances across on the safeguard plates fixed at the changing pitch gave counterfeit harshness.

Two plane mirrors on both side of collector have mounted on wood support with tilting arrangement, mirror where tilted on hourly basis to focus more radiation on the collector plates.

\section{EXPERIMENTAL SYSTEM DEVELOPMENT}

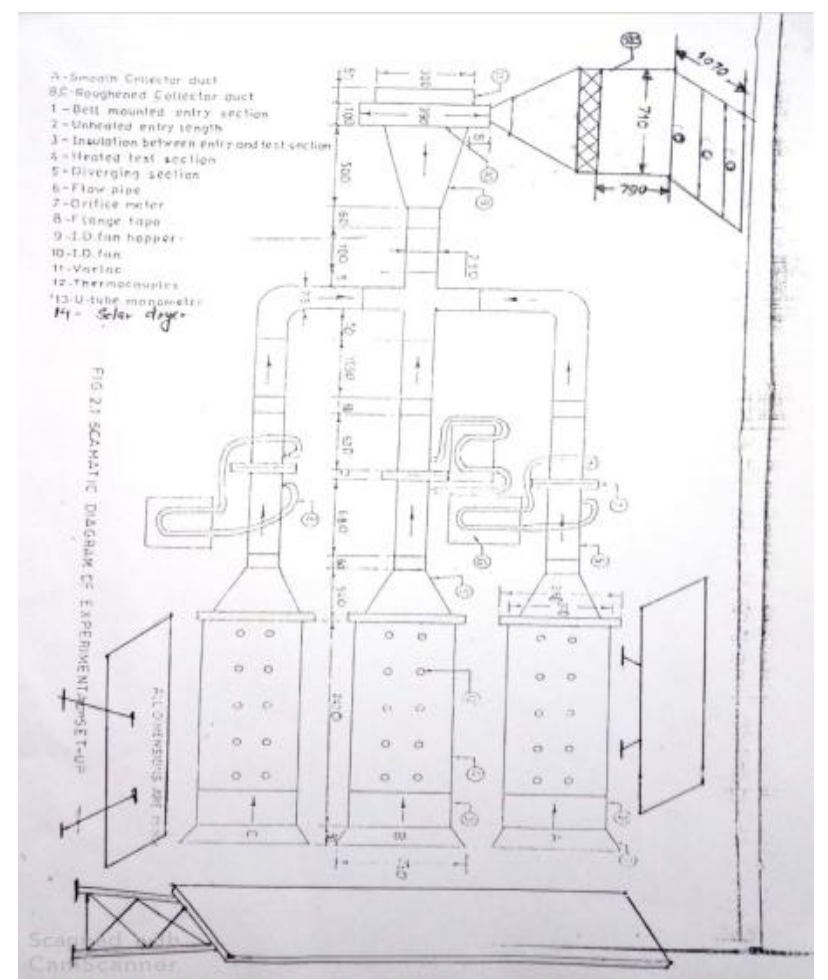

Fig 2 shows the schematic diagram of the experimental setup developed and used. The system for solar food dryer consists of the following main components

\section{A. Solar Air heater duct}

The pipe is given to concede suction air through chime formed mouth into the cupboard dryers Three pipes were utilized one having smooth safeguard plate and different items having two distinctive harshness on the ingest plate. Air hole of $25 \mathrm{~mm}$ gave between the base and safeguard plates for every two part harmony brought about a cross segment of $250 \mathrm{~mm} \times 25 \mathrm{~mm}$ each.

\section{B. Absorber plate and cover plate}

Dull dark painted 20 SWG aluminum sheets of $1.84 \mathrm{~m}$ length and $28 \mathrm{~cm}$ width were utilized. Out of $28 \mathrm{~cm}$ width, 25 $\mathrm{cm}$ shaped clear absorber width while $1.5 \mathrm{~cm}$ on each side lays on wooden support. Artificial roughness was delivered by inserting roundabout copper wires of various checks on posterior of the absorber plates of different gauges on back side of the absorber plates.

\section{Cabinet dryer}

The bureau contains the drying and structures a piece of air warmer. The bureau and air radiator channel consolidated so no tourist leaving any conduits released net of bureau two plates are given of each measurement $88 \mathrm{~cm}$ x $24 \mathrm{~cm}$ x $6 \mathrm{~cm}$ with base as fine net of wires are given. $T \neg \neg$ he tourist from air radiator goes through the nourishment item set over the plate.

\section{Flow control arrangement}

Wind stream rate through the pipe was constrained by methods for three stages fluctuated associated in arrangement with the ID fan. Voltage guideline of the changed gave consistent stockpile of capacity to run the engine of the ID fan speed. Steady mass stream rate was keeps up through the three

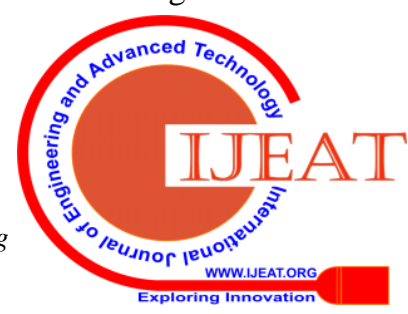


conduits in inspite of variety of out site voltage.

\section{INSTRUMENTATION AND SYSTEM ADJUSTMENT}

Instrumentation assumes an essential job in any investigation. Examination unique consideration was taken to make the estimating instrument increasingly delicate to record the information precisely. The striking highlights of the mechanical assembly utilized for instrumentation are:

\section{A. Air flow measurement}

Wind stream estimation was practiced by three indistinguishable whole meters one of every channel framework all the three opening meter were flanged tap type which were structured created aligned and fitted in the $3 "$ measurement pipe. Opening meter was aligned utilizing Pitot cylinder to decide coefficient of release. The weight distinction was estimated with $U$ tube manometer loaded up with water.

\section{B. Temperature measurement}

26SWG adjusted copper steady a thermocouple had been utilized to an estimated nearby temperature of safeguards plates. These were installed on tips of a side of safeguard plate. The temperature of the air as streams progress through sun based air warmer was estimated with the help 48 channel information hogger having 100 platinum opposition props. Encompassing air temperature was estimated utilizing standard Mercury thermometer with least check $0.1 \square \mathrm{C}$.

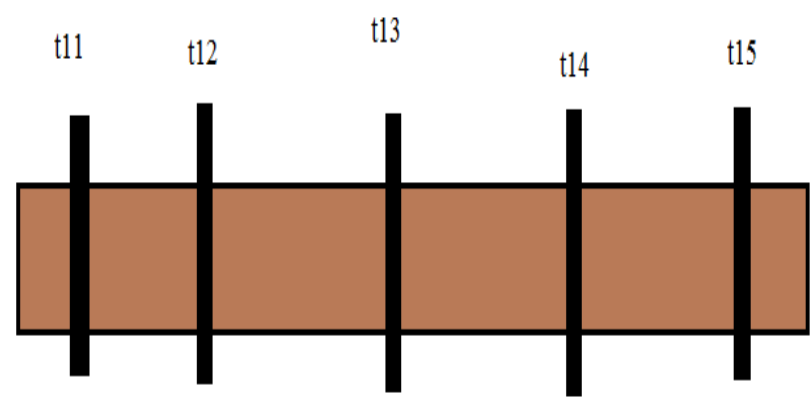

Fig 3 Thermocouple in air ducts to measure air flow temperature

\section{Solar radiation in intensity measurement}

Power of worldwide sun based radiation was estimated by pyranometer having a Calibration factor of 5.8 $\mathrm{MV} / \mathrm{Cal} / \mathrm{cm} 2 / \mathrm{min}$. The sign from pyranometer was bolstered to a computerized mili-voltmeter. The perusing of computerized mili-voltmeter were recorded in mili-volt with a least check of $01 \mathrm{mv}$, would then be changed over to force of radiation as far as $\mathrm{W} / \mathrm{m} 2(1 \mathrm{mv}=129.3 \mathrm{~W} / \mathrm{m} 2)$

\section{Wind speed measurement}

Wind speed was measured with the help of a wind monitor which provides wind speed in $\mathrm{Km} / \mathrm{hr}$.

\section{E. Pressure drop measurement across orifice meter}

The pressure difference across the three orifice meter was measured by $\mathrm{U}$ tube manometer fitted in each pipe connected in each duct.

\section{F. Humidity measurement}

The instrument used to quantify the particular moistness in psychrometer. It comprises of a dry-bulb thermometer and wet-bulb thermometer. Then two are mounted on an appropriate plate having a game plan for the constant inventory of refined water to keep the width wet on the bulb of a wet-bulb thermometer.

\section{G. Weight loss of moisture measurement}

Loss of dampness was estimated by gauging the wet nourishment item and dry nourishment item with the advanced delicate equalization. Weight of item was taken at the interim of an hour.

\section{EXPERIMENTATION AND DATA COLLECTION}

The experimental setup developed and tested for rediness has been put under experimentation and types of product investigated in the experiment and data's were collected.

Types of product tested and range of solar intensity

1.Cabbage

2.wheat

Range of solar intensity (490 to $900 \mathrm{~W} / \mathrm{m}^{2}$ )

Test data were collected at the interval of 1 hour on each day between 9AM to 2PM

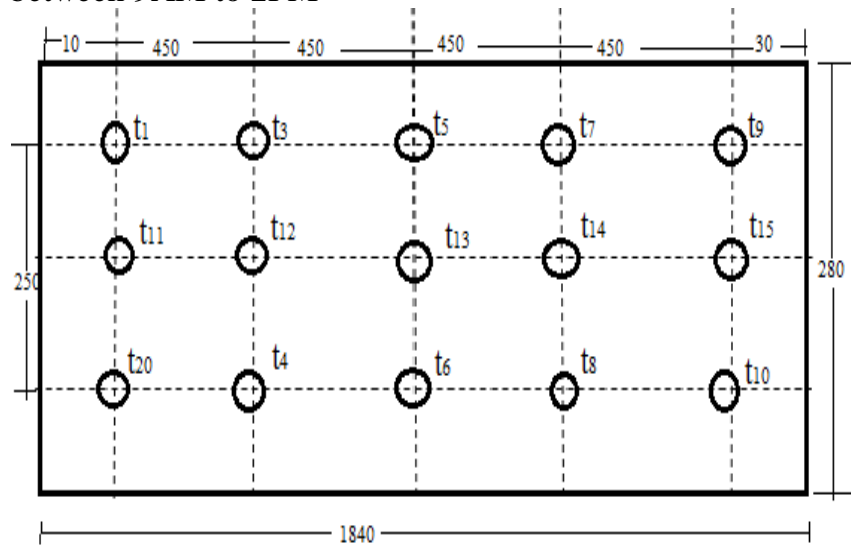

Fig 4 - Absorber plate with thermocouples to measure plates temperature.

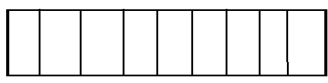

Fig 5 - thermocouple in air ducts to measure air flow temperature.

Table- I: Table 1 -Dryer Temperature and inlet and outlet temperature

\begin{tabular}{|l|l|l|l|l|}
\hline \multirow{2}{*}{ SL. No } & \multirow{2}{*}{ Time (hours) } & \multicolumn{2}{|c|}{ Solar intensity } & \multirow{2}{*}{$\begin{array}{c}\text { Thermom } \\
\text { eter } \\
\text { Reading } \\
\text { (c) }\end{array}$} \\
\cline { 3 - 4 } & & $\boldsymbol{m} . \boldsymbol{y}$ & $\boldsymbol{W} / \boldsymbol{m}^{2}$ & 32 \\
\hline 2 & $9.00 \mathrm{AM}$ & 4.65 & 601.245 & 32 \\
\hline 3 & $10.00 \mathrm{AM}$ & 5.02 & 650 & 33 \\
\hline 4 & $11.00 \mathrm{AM}$ & 5.50 & 711.15 & 33 \\
\hline 5 & $12.00 \mathrm{NOON}$ & 5.98 & 733.21 & 35.5 \\
\hline 6 & $1.00 \mathrm{PM}$ & 4.87 & 691.75 & 34 \\
\hline
\end{tabular}

\section{RESULTS}

Published By:

Blue Eyes Intelligence Engineering \& Sciences Publication

(C) Copvriaht: All riahts reserved.

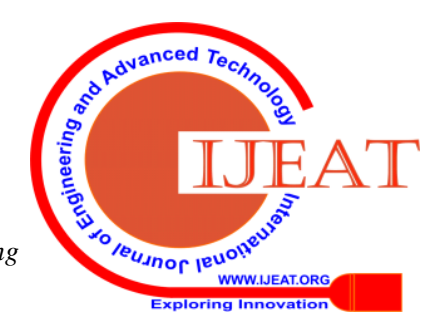


Effect of Boosting Solar Radiation Intensity on Thermal and Hydraulic Performance and Characteristics of Forced Circulation Food Dryer Provided with Roughened Solar Air Heater

Experimental data

c0.0226ollected

simultaneously for a smooth and roughened solar air heater coupled with crops dr0.0175yer have been represented graphically.

\section{A. Experimental results}

Fig. 5 shows variation of ambient temperature and solar radiation intensity with time and fig5 indicates variation of wind velocity.

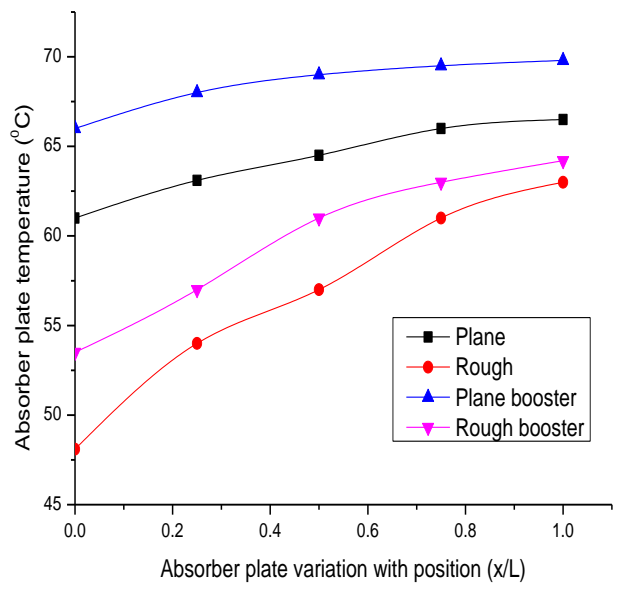

Fig. 6 shows collector plate temperature distribution at various points down the flow as a function of dimensionless length $(\mathrm{X} / \mathrm{L})$ for both smooth and roughened collector for mass flow rate of $0.386 \mathrm{~kg} / \mathrm{s}$ and roughness pitch $\mathrm{p} / \varepsilon=20$ and roughness factor $\varepsilon / \mathrm{D}=0.017$ and intensity of solar radiation $\mathrm{I}=$ $801 \mathrm{~W} / \mathrm{m}^{2}$ with booster.

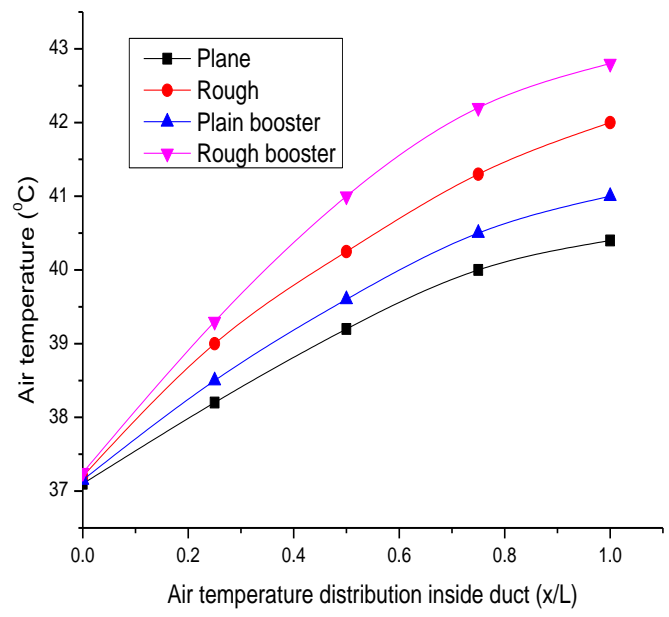

Fig. 7 indicates air temperature variation as a function of

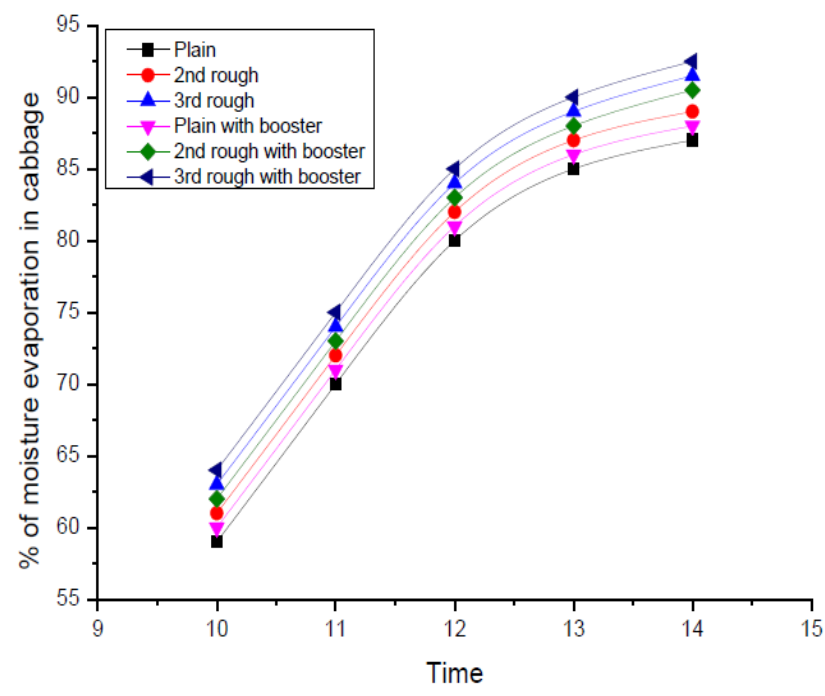

Fig. 9. indicates percentage of moisture evaporation with time for smooth and roughened collector for cabbage with booster.

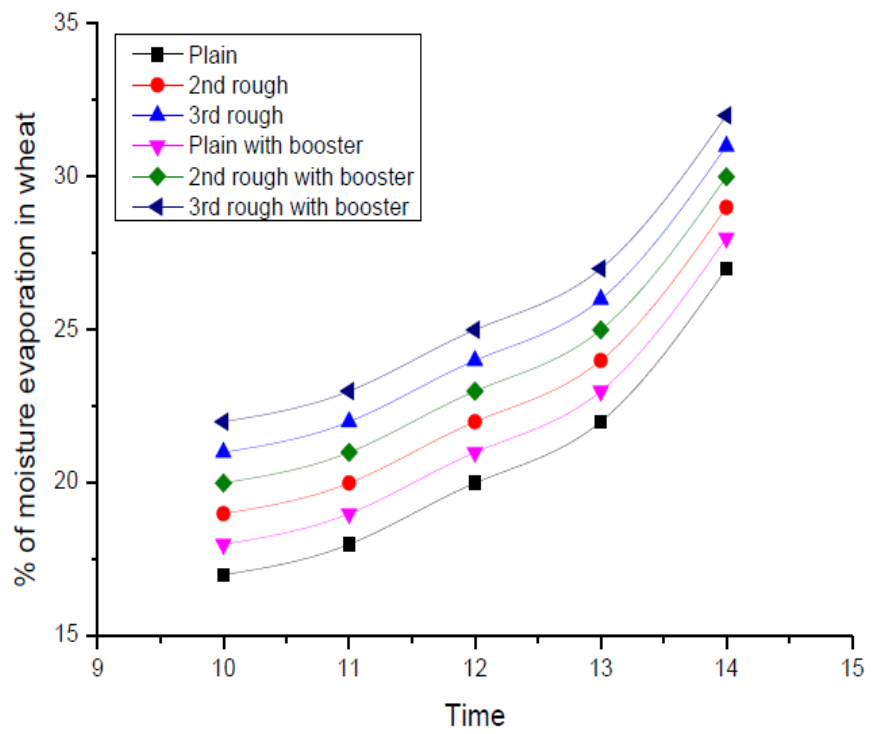

Fig. 10. indicates percentage of moisture evaporation with time for smooth and roughened collector for wheat with booster.

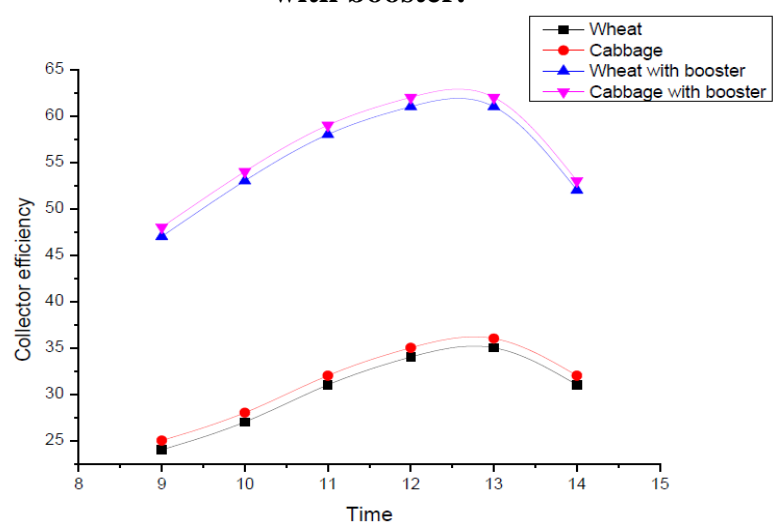

Fig.11.Indicates collector efficiency with time for smooth and roughened collector with booster.

Published By:

Blue Eyes Intelligence Engineering

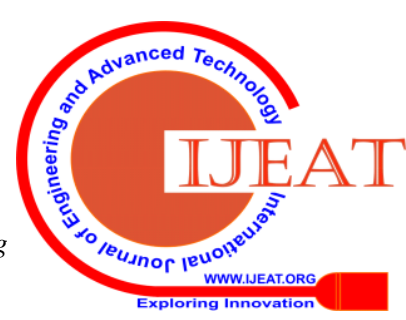


Table- II: Time and absorber plate and air temperature at different point of air heater after the boosting

\begin{tabular}{|c|c|c|c|c|c|c|c|c|c|c|c|c|c|c|c|c|c|c|c|c|}
\hline $\begin{array}{l}\text { Sl. } \\
\text { no }\end{array}$ & Time & $\begin{array}{l}\mathrm{T} \\
\mathrm{Y} \\
\mathrm{P} \\
\mathrm{e}\end{array}$ & $\mathrm{t}_{1}$ & $t_{2}$ & $t_{3}$ & $\mathrm{t}_{4}$ & $t_{5}$ & $\mathrm{t}_{6}$ & $t_{7}$ & $t_{8}$ & $t_{9}$ & $\mathrm{t}_{10}$ & $\mathrm{t}_{11}$ & $t_{12}$ & $\mathrm{t}_{13}$ & $\mathrm{t}_{14}$ & $t_{15}$ & $\Delta \mathrm{t}$ & $\mathrm{T}_{\mathrm{p}}$ & $\mathrm{T}_{\mathrm{f}}$ \\
\hline \multirow{3}{*}{1} & \multirow{3}{*}{9} & $\mathrm{~S}_{\mathrm{B}}$ & $\begin{array}{l}42 . \\
3\end{array}$ & 44 & 50 & 54 & 55.6 & $\begin{array}{l}56 . \\
5\end{array}$ & 58.3 & 59 & 61.2 & 62 & 33 & 34 & $\begin{array}{l}34 . \\
2\end{array}$ & 36 & 37 & 4 & $\begin{array}{l}54 . \\
3\end{array}$ & 34.8 \\
\hline & & $\mathrm{R}_{\mathrm{B} 1}$ & 40 & 41 & 46 & 49 & 50.1 & $\begin{array}{l}57 . \\
5\end{array}$ & 54 & $\begin{array}{l}55 . \\
5\end{array}$ & 56.3 & 57.3 & $\begin{array}{l}33 . \\
1\end{array}$ & $\begin{array}{l}35 . \\
5\end{array}$ & $\begin{array}{l}36 . \\
1\end{array}$ & $\begin{array}{l}37 . \\
8\end{array}$ & $\begin{array}{l}38 . \\
6\end{array}$ & $\begin{array}{l}5 . \\
5\end{array}$ & $\begin{array}{l}50 . \\
6\end{array}$ & 36.2 \\
\hline & & $\mathrm{R}_{\mathrm{B} 2}$ & 45 & 45.2 & 50.1 & 54.1 & 55.3 & $\begin{array}{l}62 . \\
3\end{array}$ & 59.1 & $\begin{array}{l}60 . \\
1\end{array}$ & 61.5 & 63.5 & $\begin{array}{l}38 . \\
1\end{array}$ & $\begin{array}{l}40 . \\
5\end{array}$ & $\begin{array}{l}41 . \\
2\end{array}$ & $\begin{array}{l}43 . \\
1\end{array}$ & $\begin{array}{l}44 . \\
2\end{array}$ & $\begin{array}{l}3 . \\
7\end{array}$ & $\begin{array}{l}55 . \\
6\end{array}$ & 41.4 \\
\hline \multirow{3}{*}{2} & \multirow[t]{3}{*}{10} & $\mathrm{~S}_{\mathrm{B}}$ & $\begin{array}{l}43 . \\
5\end{array}$ & 44.4 & 51.5 & 50 & 57 & $\begin{array}{l}59 . \\
5\end{array}$ & 60.6 & $\begin{array}{l}61 . \\
3\end{array}$ & 62 & 63 & $\begin{array}{l}35 . \\
2\end{array}$ & 37 & $\begin{array}{l}37 . \\
7\end{array}$ & $\begin{array}{l}38 . \\
3\end{array}$ & $\begin{array}{l}38 . \\
8\end{array}$ & $\begin{array}{l}3 . \\
6\end{array}$ & $\begin{array}{l}55 . \\
3\end{array}$ & 37.8 \\
\hline & & $\mathrm{R}_{\mathrm{B} 1}$ & $\begin{array}{l}42 . \\
5\end{array}$ & 43.1 & 47 & 55.3 & 53.4 & $\begin{array}{l}55 . \\
5\end{array}$ & 56.2 & 57 & 57.5 & 58.5 & $\begin{array}{l}35 . \\
1\end{array}$ & $\begin{array}{l}35 . \\
9 \\
\end{array}$ & $\begin{array}{l}37 . \\
1\end{array}$ & 39 & 40 & $\begin{array}{l}4 . \\
9\end{array}$ & $\begin{array}{l}52 . \\
6\end{array}$ & 37.6 \\
\hline & & $\mathrm{R}_{\mathrm{B} 2}$ & 47 & 48 & 52 & 61.2 & 57.5 & $\begin{array}{l}60 . \\
3\end{array}$ & 61.5 & 62 & 63 & 64 & $\begin{array}{l}39 . \\
2\end{array}$ & $\begin{array}{l}40 . \\
3\end{array}$ & $\begin{array}{l}42 . \\
5\end{array}$ & 44 & 46 & $\begin{array}{l}6 . \\
8\end{array}$ & $\begin{array}{l}57 . \\
7\end{array}$ & 42.4 \\
\hline \multirow{3}{*}{3} & \multirow[t]{3}{*}{11} & $\mathrm{~S}_{\mathrm{B}}$ & 44 & 45 & 52.1 & 50.4 & 57.4 & 60 & 66 & 62 & 63 & 63 & $\begin{array}{l}35 . \\
8\end{array}$ & $\begin{array}{l}37 . \\
2\end{array}$ & $\begin{array}{l}37 . \\
2\end{array}$ & 38 & $\begin{array}{l}39 . \\
1\end{array}$ & $\begin{array}{l}3 . \\
3\end{array}$ & $\begin{array}{l}56 . \\
3\end{array}$ & 37.5 \\
\hline & & $\mathrm{R}_{\mathrm{B} 1}$ & 43 & 44 & 47.4 & 50.5 & 53.5 & $\begin{array}{l}55 . \\
5\end{array}$ & 56.5 & 58 & 59 & 59.4 & 36 & $\begin{array}{l}36 . \\
5\end{array}$ & $\begin{array}{l}38 . \\
2\end{array}$ & 40 & $\begin{array}{l}40 . \\
5\end{array}$ & $\begin{array}{l}4 . \\
5\end{array}$ & $\begin{array}{l}52 . \\
6\end{array}$ & 38.7 \\
\hline & & $\mathrm{R}_{\mathrm{B} 2}$ & 47 & 49 & 52 & 55.6 & 57.5 & $\begin{array}{l}60 . \\
2 \\
\end{array}$ & 62 & 64 & 64.5 & 64.3 & 41 & $\begin{array}{l}42 . \\
1 \\
\end{array}$ & $\begin{array}{l}44 . \\
5 \\
\end{array}$ & $\begin{array}{l}45 . \\
1 \\
\end{array}$ & $\begin{array}{l}45 . \\
3\end{array}$ & $\begin{array}{l}4 . \\
3 \\
\end{array}$ & $\begin{array}{l}58 . \\
1 \\
\end{array}$ & 43.6 \\
\hline \multirow{3}{*}{4} & \multirow{3}{*}{12} & $\mathrm{~S}_{\mathrm{B}}$ & $\begin{array}{l}44 . \\
3\end{array}$ & 46 & 53.1 & 51.1 & 57.7 & $\begin{array}{l}60 . \\
5\end{array}$ & 61.5 & $\begin{array}{l}62 . \\
5\end{array}$ & 63.5 & 64 & $\begin{array}{l}37 . \\
3\end{array}$ & $\begin{array}{l}37 . \\
5\end{array}$ & $\begin{array}{l}37 . \\
8 \\
\end{array}$ & $\begin{array}{l}38 . \\
2\end{array}$ & 41 & $\begin{array}{l}3 . \\
5\end{array}$ & $\begin{array}{l}56 . \\
4\end{array}$ & 38.3 \\
\hline & & $\mathrm{R}_{\mathrm{B} 1}$ & $\begin{array}{l}43 . \\
2\end{array}$ & 45.4 & 48.1 & 51.4 & 53.7 & 55 & 57 & 59 & 62 & 61 & 37 & $\begin{array}{l}37 . \\
6\end{array}$ & $\begin{array}{l}38 . \\
5\end{array}$ & $\begin{array}{l}39 . \\
1\end{array}$ & 40 & $\begin{array}{l}2 . \\
4\end{array}$ & $\begin{array}{l}53 . \\
5\end{array}$ & 38.4 \\
\hline & & $\mathrm{R}_{\mathrm{B} 2}$ & $\begin{array}{l}48 . \\
3 \\
\end{array}$ & 50.2 & 54.1 & 55.6 & 62.3 & 60 & 62 & $\begin{array}{l}64 . \\
2 \\
\end{array}$ & 64 & 66 & 43 & $\begin{array}{l}43 . \\
9 \\
\end{array}$ & $\begin{array}{l}44 . \\
5 \\
\end{array}$ & 46 & $\begin{array}{l}46 . \\
3\end{array}$ & $\begin{array}{l}3 . \\
3\end{array}$ & $\begin{array}{l}57 . \\
6\end{array}$ & 44.7 \\
\hline \multirow{3}{*}{5} & \multirow{3}{*}{13} & $\mathrm{~S}_{\mathrm{B}}$ & $\begin{array}{l}46 . \\
9\end{array}$ & 49.1 & 57 & 53.5 & 60 & $\begin{array}{l}61 . \\
8\end{array}$ & 62.8 & 63 & 63.1 & 63.5 & $\begin{array}{l}37 . \\
8\end{array}$ & 39 & $\begin{array}{l}39 . \\
8\end{array}$ & $\begin{array}{l}40 . \\
3\end{array}$ & $\begin{array}{l}41 . \\
5\end{array}$ & $\begin{array}{l}3 . \\
7\end{array}$ & $\begin{array}{l}58 . \\
3\end{array}$ & 39.6 \\
\hline & & $\mathrm{R}_{\mathrm{B} 1}$ & $\begin{array}{l}44 . \\
5\end{array}$ & 46.5 & 57.4 & 58.1 & 56.6 & $\begin{array}{l}57 . \\
5 \\
\end{array}$ & 58.5 & 59 & 61 & 61.5 & $\begin{array}{l}37 . \\
7\end{array}$ & $\begin{array}{l}39 . \\
2 \\
\end{array}$ & $\begin{array}{l}39 . \\
9 \\
\end{array}$ & $\begin{array}{l}40 . \\
5\end{array}$ & $\begin{array}{l}41 . \\
6\end{array}$ & $\begin{array}{l}3 . \\
9 \\
\end{array}$ & $\begin{array}{l}55 . \\
4\end{array}$ & 39.8 \\
\hline & & $\mathrm{R}_{\mathrm{B} 2}$ & 59 & 51.1 & 62.3 & 64.1 & 61.1 & $\begin{array}{l}62 . \\
5 \\
\end{array}$ & 62.8 & 64 & 66 & 66.5 & 43 & $\begin{array}{l}44 . \\
5\end{array}$ & 46 & $\begin{array}{l}45 . \\
2\end{array}$ & $\begin{array}{l}46 . \\
1\end{array}$ & $\begin{array}{l}3 . \\
1 \\
\end{array}$ & $\begin{array}{l}59 . \\
1\end{array}$ & 44.9 \\
\hline \multirow{3}{*}{6} & \multirow{3}{*}{15} & $\mathrm{~S}_{\mathrm{B}}$ & 48 & 44.5 & 57.4 & 59 & 59.5 & 61 & 61.6 & 63 & 63.5 & 63.7 & $\begin{array}{l}37 . \\
6\end{array}$ & $\begin{array}{l}40 . \\
3\end{array}$ & 41 & $\begin{array}{l}41 . \\
7\end{array}$ & $\begin{array}{l}42 . \\
3\end{array}$ & $\begin{array}{l}4 . \\
7\end{array}$ & $\begin{array}{l}52 . \\
7\end{array}$ & 48.9 \\
\hline & & $\mathrm{R}_{\mathrm{B} 1}$ & 45 & 46 & 52 & 56 & 56.1 & 58 & 58.5 & 60 & 61 & 61.5 & $\begin{array}{l}37 . \\
8\end{array}$ & 41 & 42 & 42 & $\begin{array}{l}42 . \\
5\end{array}$ & $\begin{array}{l}4 . \\
7\end{array}$ & $\begin{array}{l}55 . \\
4\end{array}$ & 49.1 \\
\hline & & $\mathrm{R}_{\mathrm{B} 2}$ & 50 & 51 & 57 & 61 & 61.2 & 64 & 64.2 & $\begin{array}{l}64 . \\
5\end{array}$ & 66 & 66.2 & $\begin{array}{l}42 . \\
2\end{array}$ & 46 & 47 & 46 & $\begin{array}{l}46 . \\
5\end{array}$ & $\begin{array}{l}4 . \\
3\end{array}$ & $\begin{array}{l}59 . \\
6\end{array}$ & 45.5 \\
\hline \multirow{3}{*}{7} & \multirow{3}{*}{16} & $\mathrm{~S}_{\mathrm{B}}$ & $\begin{array}{l}48 . \\
5\end{array}$ & 50 & 57.5 & 59 & 58 & $\begin{array}{l}60 . \\
5 \\
\end{array}$ & 61.5 & $\begin{array}{l}61 . \\
7 \\
\end{array}$ & 62.8 & 63 & $\begin{array}{l}37 . \\
8 \\
\end{array}$ & $\begin{array}{l}42 . \\
2 \\
\end{array}$ & $\begin{array}{l}42 . \\
8 \\
\end{array}$ & $\begin{array}{l}43 . \\
4\end{array}$ & 44 & $\begin{array}{l}6 . \\
2 \\
\end{array}$ & $\begin{array}{l}58 . \\
3 \\
\end{array}$ & 42.1 \\
\hline & & $\mathrm{R}_{\mathrm{B} 1}$ & $\begin{array}{l}45 . \\
5\end{array}$ & 46.5 & 53 & 57 & 55.5 & $\begin{array}{l}57 . \\
6 \\
\end{array}$ & 65.8 & $\begin{array}{l}58 . \\
5\end{array}$ & 59 & 59 & 37 & $\begin{array}{l}42 . \\
3 \\
\end{array}$ & $\begin{array}{l}42 . \\
9 \\
\end{array}$ & $\begin{array}{l}43 . \\
9\end{array}$ & $\begin{array}{l}44 . \\
6\end{array}$ & $\begin{array}{l}7 . \\
6 \\
\end{array}$ & $\begin{array}{l}55 . \\
7\end{array}$ & 50.9 \\
\hline & & $\mathrm{R}_{\mathrm{B} 2}$ & $\begin{array}{l}50 . \\
1\end{array}$ & 51.3 & 57.1 & 62.1 & 60.5 & $\begin{array}{l}62 . \\
3 \\
\end{array}$ & 70.2 & $\begin{array}{l}64 . \\
1\end{array}$ & 63 & 64 & 43 & $\begin{array}{l}47 . \\
1\end{array}$ & $\begin{array}{l}47 . \\
8\end{array}$ & $\begin{array}{l}48 . \\
1\end{array}$ & 49 & 6 & $\begin{array}{l}60 . \\
1\end{array}$ & 47 \\
\hline
\end{tabular}

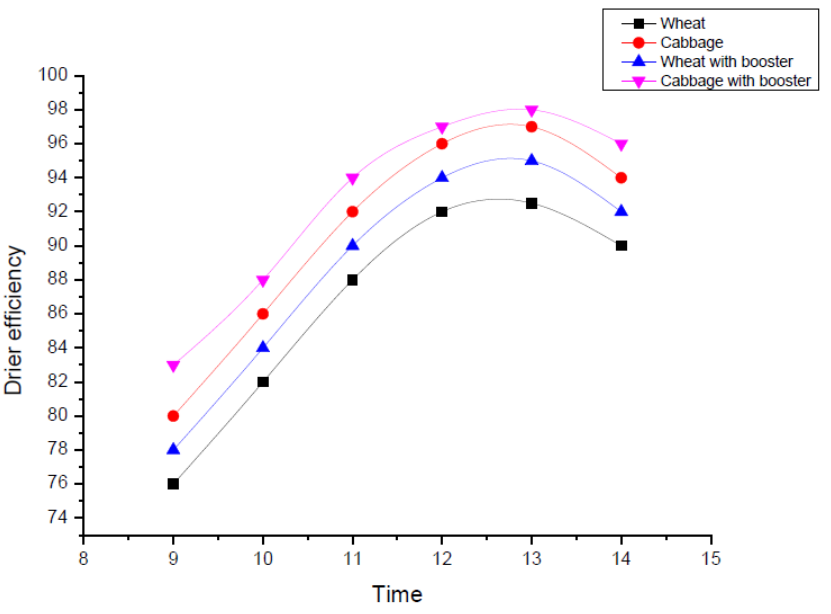

Fig.12. Indicates dryer efficiency with time for wheat and cabbage with booster

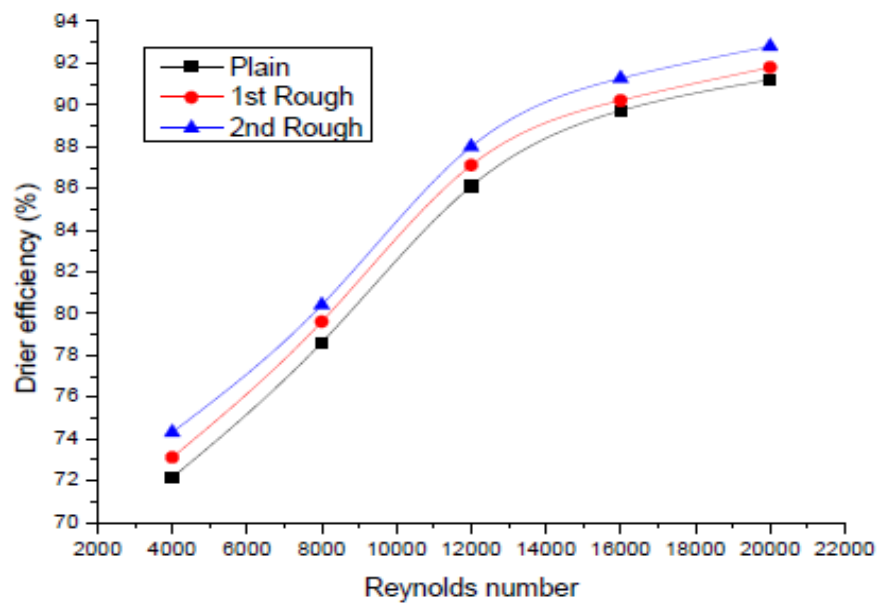

Fig.13. indicates efficiency versus Reynolds no with booster
Published By:

Blue Eyes Intelligence Engineering

\& Sciences Publication

(c) Copvriaht: All riahts reserved.

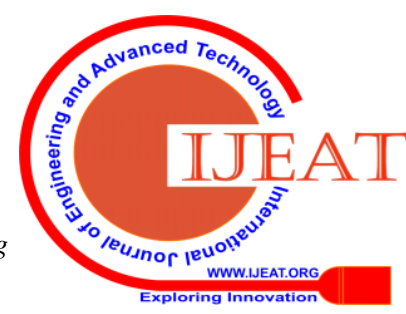




\section{RESULTS}

The various experimental results for smooth and roughened solar air heater attached with crops dryer have been represented. These experimental results have been utilized and workout for values of collector performance parameters (plate temperature, air temperature and efficiency) and performance of dryer (temperature, humidity and efficiency) with solar intensity, time and different roughness factors.

\section{A. Effect of relative roughness height $(\varepsilon / D)$ on the absorber plate temperature $\left(t_{p}\right)$}

Fig 6 shows the typical effect of roughness factor on plate temperature. There is a remarkable effect of roughness factor $(\varepsilon / D)$ on the plate temperature. It is observed that plate temperature decreases due to creating turbulence in the flow which enhances more heat transfer from the absorber plate to air entering into the duct. For example, for given values of flow parameter there has been decrease in plate temperature about $15 \%$ compared to smooth collector plate. This percentage decrease of temperature increased with increasing roughness factor $(\varepsilon / D)$.

\section{B. Effect of relative roughness height $(\varepsilon / D)$ on increase in rise of air temperature in the duct}

Fig 7 represents variation of air temperature at various positions of air duct. It shows that air temperature rises in the direction of flow but rise in air temperature is slower near outlet than near inlet. It is also observed that rise in temperature of $\operatorname{air}\left(\Delta \mathrm{t}_{\mathrm{a}}\right)$ is much more in rough collector duct than in smooth collector plate which indicates roughened collector absorber plate is more efficient than smooth collector plate. The increase in air temperature increases with increasing surface roughness factor $(\varepsilon / \mathrm{D})$.

\section{Effect of relative roughness height $(\varepsilon / D)$ on efficiency of solar air heater}

Fig 8 shows variation of efficiency of solar air heater with relative roughness height $(\varepsilon / D)$. It is observed that efficiency of roughened solar air heater is more than smooth air heater. This is due to increase in heat transfer from absorber plate to air due to more turbulence in the flow. Higher the roughness factor ( $\varepsilon / D)$, higher is efficiency. Thermal efficiency of roughened solar air heater are found to be $42 \%, 46.5 \%$ and $51.5 \%$ for $\varepsilon / D$ relative roughness height $0.0145,0.0220$ and

0.0288 respectively as compared to thermal efficiency of smooth air heater as $28.5 \%$.

\section{Effect of relative roughness height $(\varepsilon / D)$ on temperature variation in the crops/food dryer}

Fig 9 shows temperature variation with time inside the crops dryer. It is observed that temperature inside the dryer increases with time. However, increase is gradual as increasing time. It is concluded that increase in air temperature indicates higher moisture transfer from crops to air passing through crops dryer.

\section{E. Effect of relative roughness height $(\varepsilon / D)$ on dryer efficiency}

Fig 13 shows variation of dryer efficiency with time for smooth and roughened solar air heater duct coupled with dryer. It indicates dryer efficiency is higher in case of roughened solar air heater. It is also observed that as relative roughness height increases, dryer efficiency also increases. It is further observed that rate of moisture transfer from crops having higher initial moisture is more than the crops having lower initial moisture content.

\section{CONCLUSION}

1. Effect of boosting of intensity of solar radiation has more pronounced effect on collector efficiency, dryer efficiency, and loss of moisture content on the food product having more moisture content. Food dryer used for cauliflower has $12 \%$ more efficiency than used for wheat drying as cauliflower has more moisture content than wheat. Similarly loss of moisture evaporated in cabbage is $17 \%$ more than wheat in the same time.

2. The values of range of enhance factors are: For collector efficiency:

3. It is investigated that moderate temperature range $40^{\circ} \mathrm{C}$ to $60^{\circ} \mathrm{C}$ can be achieved easily in solar air heater without booster mirrors and higher temperature range $60^{\circ} \mathrm{C}$ to $75^{\circ} \mathrm{C}$ using booster mirrors. Much higher temperature can be achieved using parabolic concentrating mirrors. Higher temperature is more essential for drying food products like grapes, dates and some vegetables without using any other external source of energy.

4. Boosting intensity of radiation does not affect pressure drop or friction inside collector and dryer.

5. Drying time of products is considerably reduced using booster mirrors by 20 to 25 percent.

6. .It is further investigated that effect of boosting radiation intensity has more pronounced effect in winter than in summer.

7. Boosting of intensity has dominant effect on products having higher initial moisture content.

\section{ACKNOWLEDGMENT}

Authors would like to thanks department of Mechanical Engineering, B. I. T Sindri, Dhanbad, India for providing research facilities.

\section{REFERENCES}

1. R. Arsad and S. Tariq "International Conference on Robotics and emerging allied technology in engineering”, Pakistan, April'23-24, 20 14.

2. I. L. Muhammad, M. M. aliyu and I. Gerba, The effect of booster mirror reflector on the thermal performance of truncated pyramid solar thermal cooker, International Journal of engineering research and applications, 2017, 9622..

3. P. Pannerselvam, L. Subramanian and V. Perumal, " Solar energy fed single phase inverter through boost converter " International journal of science, engineering and technology research, 2014, 3, pp. 3422- 3426.

4. M. Bilal, M. N. Arab and M. Zain, "Increasing output power and efficiency of solar panel by using concentrator photovoltaic (CPU) ", International Journal of engineering works, 2016, 3, pp. 98-102.

5. Z. Wu, Y. Yan and Y. Di," Experiment on increasing solar radiation for building by using smart mirror," J. Asian Archit. Build." 2019, 18, PP. 200-206.

6. J. M. Pearce, Can mirror boost solar panel output and help overcome trum's tariffs",Michigan Technological University, PMEST , Jan 2018. p. 43.

7. W. T. Xie, Y. J. Dai, R. Z. Wang and K. Sumpathy, "Experiment on concentrated solar energy application using frensel lenses and renewable and sustainable reviews", 2011, 15, pp. 2588-2606.

Published By:

Blue Eyes Intelligence Engineering

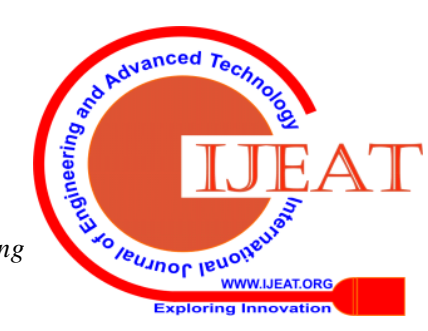




\section{AUTHORS PROFILE}

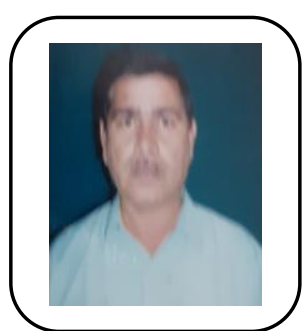

Manoj Kumar Singh received his B.Sc Engineering degree in Mechanical Engineering from Muzzaffarpur Institute of Technology (M.I..T), Muzzaffarpur, Bihar, India and M.Sc Engg from B. I.T Sindri, Dhanbad, India. He is currently pursuing $\mathrm{Ph}$. D. His area of research is Thermal Engineering. Presently, He is working as associate professor in the department of Mechanical Engineering..

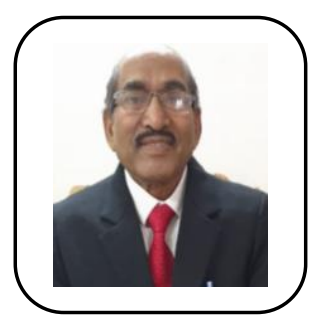

Gupta Nath Sah received his M.Tech and Ph. D degree from Indian Institute of Technology (I. I. T) Kanpur. His area of research is solar energy. He was Ex. Professor in the department of Mechanical Engineering, B. I.T Sindri, Dhanbad, India.

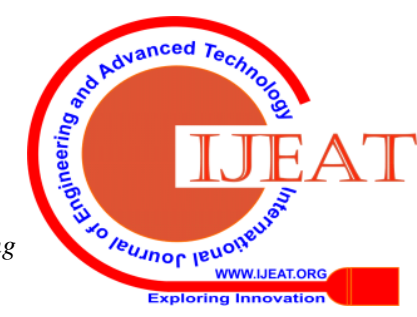

